\title{
Duurzaamheid : wetenschap of fictie?
}

Citation for published version (APA):

Martens, P. (2005). Duurzaamheid : wetenschap of fictie? Maastricht University. https://doi.org/10.26481/spe.20050225pm

Document status and date:

Published: 25/02/2005

DOI:

10.26481/spe.20050225pm

Document Version:

Publisher's PDF, also known as Version of record

\section{Please check the document version of this publication:}

- A submitted manuscript is the version of the article upon submission and before peer-review. There can be important differences between the submitted version and the official published version of record.

People interested in the research are advised to contact the author for the final version of the publication, or visit the DOI to the publisher's website.

- The final author version and the galley proof are versions of the publication after peer review.

- The final published version features the final layout of the paper including the volume, issue and page numbers.

Link to publication

\footnotetext{
General rights rights.

- You may freely distribute the URL identifying the publication in the public portal. please follow below link for the End User Agreement:

www.umlib.nl/taverne-license

Take down policy

If you believe that this document breaches copyright please contact us at:

repository@maastrichtuniversity.nl

providing details and we will investigate your claim.
}

Copyright and moral rights for the publications made accessible in the public portal are retained by the authors and/or other copyright owners and it is a condition of accessing publications that users recognise and abide by the legal requirements associated with these

- Users may download and print one copy of any publication from the public portal for the purpose of private study or research.

- You may not further distribute the material or use it for any profit-making activity or commercial gain

If the publication is distributed under the terms of Article $25 \mathrm{fa}$ of the Dutch Copyright Act, indicated by the "Taverne" license above, 


\section{Oratie \\ Universiteit Maastricht Open Universiteit Nederland \\ Hogeschool Zuyd}

\section{Pim Martens}

\section{Duurzaamheid: wetenschap of fictie?}

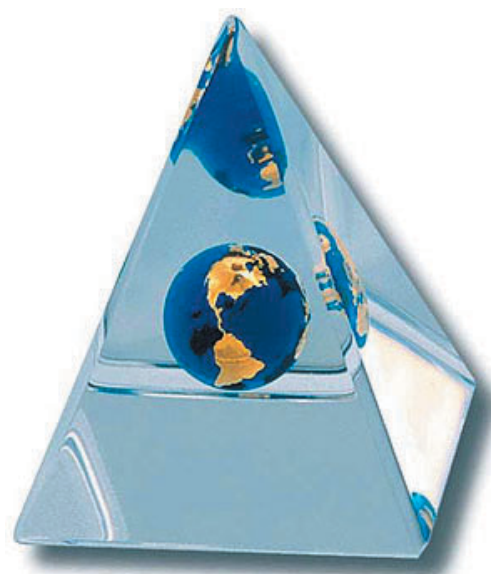


Duurzaamheid: wetenschap of fictie? 


\section{Colofon}

Basisontwerp en realisatie: Unigraphic, Universiteit Maastricht.

Tekstcorrectie: Coenegracht Tekst \& Communicatie.

ISBN 90-5681-0006

NUR 741

Alle rechten voorbehouden. Niets uit deze uitgave mag worden verveelvoudigd, opgeslagen in een geautomatiseerd gegevensbestand of openbaar gemaakt, zonder voorafgaande schriftelijke toestemming van de auteur of uitgever. 


\section{Duurzaamheid: wetenschap of fictie?}

sus.tain.abil.i.ty noun

1: capability of being sustained; 2a: of, relating to, or being a method of harvesting or using a resource so that the resource is not depleted or permanently damaged <sustainable techniques〉 〈sustainable agriculture> b: of or relating to a lifestyle involving the use of sustainable methods <sustainable society>

Merriam-Webster

\section{Rede}

Uitgesproken bij de aanvaarding van het ambt van bijzonder hoogleraar 'Duurzame Ontwikkeling' aan de Universiteit Maastricht, Open Universiteit Nederland en Hogeschool Zuyd

op vrijdag 25 februari 2005

door

Pim Martens 
Duurzaamheid: wetenschap of fictie? 
Mijnheer de Rector Magnificus, zeer geachte toehoorders,

\section{Wat is duurzame ontwikkeling?}

De essentie van duurzame ontwikkeling is: voorzien in de fundamentele behoeften van de mens - zonder geweld te doen aan de natuurlijke leefsystemen op aarde. Dit idee ontstond in de vroege jaren tachtig van de vorige eeuw en vloeide voort uit een wetenschappelijke kijk op de verhouding tussen de natuur en de maatschappij. Het concept 'duurzame ontwikkeling' reflecteerde het streven van de wereldbevolking naar vrede, vrijheid, verbeterde leefomstandigheden en een gezond milieu [1]. Deze vier doelen kwamen gedurende de laatste helft van de zoe eeuw regelmatig als wereldwijde kernidealen naar voren.

Met het einde van de Tweede Wereldoorlog in 1945 geloofde men dat het eerste doel - vrede - een feit was. Maar toen kwam de kernwapenwedloop en terwijl er globaal gezien wél vrede heerste, leidde de Koude Oorlog tot plaatselijk uitgevochten conflicten. Vandaag de dag is vrede in een groot aantal delen van de wereld - denk aan het Midden-Oosten en Midden-Afrika - nog steeds ver te zoeken.

Onder het vaandel van vrijheid vocht men voor de verbreiding van mensenrechten en voor nationale onafhankelijkheid. Nu is 'ontwikkeling' het belangrijkste doel van het armste deel van de mensheid. Tweederde van de wereldbevolking hoopt hierdoor dezelfde materiële welvaart te bereiken als het rijke deel.

Een ideaal waar sinds kort veel nadruk op ligt, heeft met de aarde zelf te maken. Het begon met bezorgdheid over de uitputting van onze natuurlijke hulpbronnen. Later zag men in dat ook een verstoring van de ingewikkelde systemen die ons leven op aarde ondersteunen, grote consequenties kan hebben.

Kenmerkend voor de laatste 25 jaar is de poging om de vier genoemde idealen - vrede, vrijheid, verbeterde leefomstandigheden en een gezond milieu - met elkaar te verbinden [1]. Deze ambitie is ingegeven door het besef dat het streven naar één van die idealen vaak betekent dat de anderen óók nagestreefd moeten worden. Dit streven naar 'duurzame ontwikkeling' is één van de grote uitdagingen voor onze huidige samenleving. 
Duurzame ontwikkeling is een complex begrip dat niet eenduidig beschreven en toegepast kan worden. Er bestaan tientallen verschillende definities, maar laten we ons beperken tot de meest geciteerde, die van de Brundtland Commissie (1987) [2]:

"Duurzame ontwikkeling is een ontwikkeling die voorziet in de behoeften van de huidige generatie, zonder het vermogen aan te tasten om te voorzien in de behoeften van de toekomstige generaties".

Als we kijken naar de grootste gemene deler van de verschillende definities en interpretaties van duurzame ontwikkeling, zien we vier gemeenschappelijke kenmerken [3]. Het eerste geeft aan dat duurzame ontwikkeling een intergenerationeel fenomeen is: het is een proces van overdracht van de ene naar de andere generatie. Als we dus iets zinnigs over duurzame ontwikkeling willen zeggen, moeten we eigenlijk een tijdsperiode van ten minste twee generaties beschouwen. De tijdsdimensie die bij duurzame ontwikkeling hoort, is dus ongeveer 25 tot 50 jaar.

Het tweede gemeenschappelijke kenmerk is schaalniveau. Duurzame ontwikkeling speelt zich af op verschillende schaalniveaus, variërend van mondiaal tot regionaal en lokaal. Wat op nationale schaal als duurzaam kan worden gezien, hoeft op internationale schaal helemaal niet duurzaam te zijn. Dat heeft alles te maken met afwentelingsmechanismen, waardoor negatieve gevolgen voor een bepaald land of regio worden afgewenteld op andere landen of regio's.

Het derde gemeenschappelijke kenmerk is dat van de meervoudige domeinen. Duurzame ontwikkeling omvat ten minste een drietal domeinen: het economische, het ecologische en het sociaal-culturele domein. Voor elk van deze domeinen kan duurzame ontwikkeling worden gedefinieerd, maar het is juist de samenhang tussen de domeinen die van belang is.

Duurzame sociale ontwikkeling richt zich op de ontwikkeling van mensen en maatschappijen, waarbij rechtvaardigheid, leefbaarheid en gezondheid een belangrijke rol spelen. Bij duurzame economische ontwikkeling staat de economische infrastructuur centraal en is een efficiënt management van natuurlijke en sociale hulpbronnen belangrijk. Bij duurzame ecologische ontwikkeling staat de groei van natuurlijke 
systemen voorop en speelt het behoud van onze natuurlijke hulpbronnen een belangrijke rol.

Het betreft hier drie verschillende vormen van duurzame ontwikkeling die in theorie niet strijdig hoeven te zijn, maar in de praktijk vaak op gespannen voet met elkaar staan. De onderliggende beginselen zijn ook wezenlijk anders: bij duurzame economische ontwikkeling speelt het begrip efficiency een leidende rol, bij duurzame sociale ontwikkeling het begrip rechtvaardigheid en bij duurzame ecologische ontwikkeling het begrip veerkracht of herstelvermogen.

Het laatste gemeenschappelijke kenmerk betreft de meervoudige interpretatie van duurzame ontwikkeling. Elke definitie van duurzame ontwikkeling vereist een inschatting van de huidige en toekomstige maatschappelijke behoeften en hoe daarin kan worden voorzien. Een dergelijke inschatting kan nauwelijks objectief zijn. Bovendien is zo'n inschatting omgeven met de nodige onzekerheden. Dientengevolge kan het begrip duurzame ontwikkeling vanuit verschillende perspectieven worden geïnterpreteerd en uitgewerkt.

Zoals uit het voorgaande blijkt, is een begrip als duurzame ontwikkeling moeilijk grijpbaar. Omdat het van nature complex, normerend, subjectief en tweeslachtig is, heeft het criticasters op zowel sociaal als wetenschappelijk vlak. Eén manier om uit het 'duurzaamheidsdilemma' te komen, is beginnen aan de andere kant: bij niet-duurzame ontwikkeling. Niet-duurzame of onduurzame ontwikkeling zien we terug in een aantal hardnekkige problemen die in onze sociale stelsels zijn geslopen en die niet door het huidige beleid opgelost kunnen worden. Deze hardnekkige problemen kenmerken zich door een grote complexiteit, gebrek aan structuur, vele belanghebbenden, structurele onzekerheid en een gebrek aan beheersbaarheid.

Zulke problemen zijn in vele nationale en mondiale sectoren te herkennen. In de landbouw bijvoorbeeld, met zijn vele facetten van onduurzaamheid die zich manifesteren in de vorm van door proteïne veroorzaakte ziektes zoals BSE ('gekke koeienziekte'), en mond- en klauwzeer. In de watersector, die kampt met symptomen als overstromingen, droogtes en waterkwaliteitsproblemen. In de energiesector, die op een eenzijdige manier energie levert en daardoor het milieu aantast. In het verkeers- en transportsysteem, waar luchtvervuiling en files als sympto- 
men van onduurzaamheid kunnen worden gezien. En wat onze gezondheid betreft: de verspreiding van SARS, de werelwijde toename van malaria, ondervoeding en - aan de andere kant - toename van zwaarlijvigheid, zijn verre van duurzaam.

Deze onduurzame ontwikkelingen zijn een weerspiegeling van systeemfouten die in onze samenleving zijn geslopen. In tegenstelling tot marktfouten hebben systeemfouten te maken met diepliggende gebreken in onze maatschappij. Zij kunnen niet door 'de markt' worden opgelost en vormen een ernstige barrière voor het optimaal functioneren van onze maatschappelijke systemen. Systeemfouten werken op diverse niveaus en kunnen economisch, sociaal of institutioneel van aard zijn. Als hardnekkige problemen een signaal zijn van een onduurzame ontwikkeling, dan moeten ze worden opgelost met fundamentele veranderingen in onze maatschappij - om zo een niet-duurzame toestand tot een duurzame om te buigen.

Aan de hand van een voorbeeld zal ik een aantal van de eerder genoemde elementen van (on)duurzaamheid nader bespreken.

\section{Mondialisering en gezondheid: naar een duurzame toekomst?}

Gezondheid kan gezien worden als een belangrijke integrerende index die de status - en op lange termijn de duurzaamheid - van ons milieu en onze maatschappelijk-economische omgeving weerspiegelt (Figuur 1) [4]. Vanuit een meer antropocentrische benadering kan ook

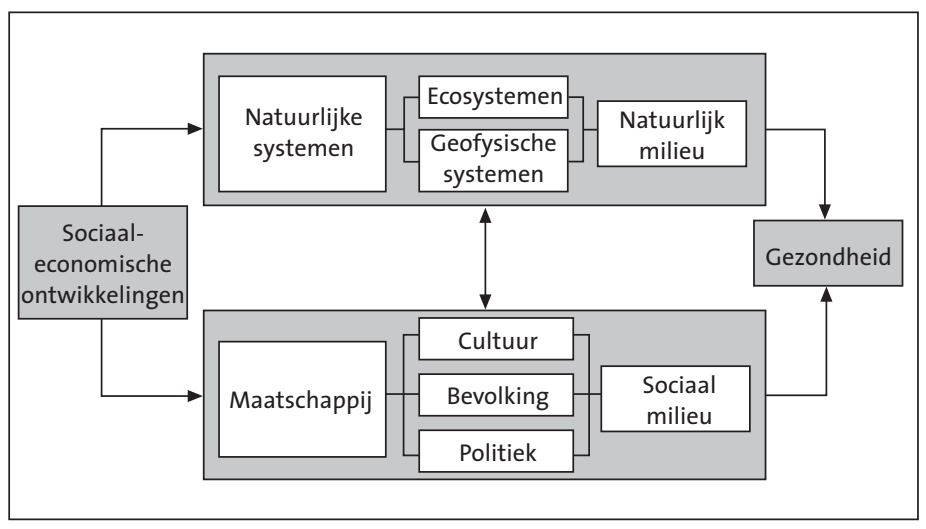

Figuur 1: Gezondheid als een geïntegreerde duurzaamheidsindex. 
gesteld worden dat, wil duurzame ontwikkeling een zekere betekenis hebben, mensen gezond genoeg moeten zijn om ervan te profiteren. Met andere woorden: duurzame ontwikkeling zonder gezondheid is van weinig waarde [5]. Laten we dit eens nader - vanuit een mondiale invalshoek - analyseren.

Gezien vanuit het perspectief van de volksgezondheid lijken de mondiale veranderingen die we de afgelopen jaren hebben gezien zowel een vloek als een zegen. Enerzijds hebben de verhoogde economische groei en snelle technologische ontwikkelingen de gezondheid en levensverwachting van veel bevolkingsgroepen verbeterd. Anderzijds brengen veel aspecten van mondialisering de volksgezondheid in gevaar. Denk hierbij onder meer aan de erosie van de sociale omstandigheden en het milieu, aan de mondiale verdeling van werk, aan de verbreding van de kloof tussen arm en rijk (zowel binnen een land als tussen landen onderling) en aan de versnelde consumptieve groei.

De relatie tussen mondialisering en gezondheid omvat zowel lokale als mondiale processen. Zij speelt op de korte én op de lange termijn en behelst zowel ecologische, sociale als economische systemen. Alle eerder genoemde componenten van 'duurzaamheid' vinden we dus hier terug.

\section{De gezondheidstransitie}

Zoals gezegd is de afgelopen decennia onze levensverwachting enorm gestegen. In de meest ontwikkelde landen is de gemiddelde levensverwachting tegenwoordig zelfs hoger dan 70 jaar. Uit onderzoek naar de veranderingen in onze gezondheid blijkt dat tijdens deze transitie een aantal veranderingen plaatsvinden die op elkaar ingrijpen en elkaar versterken:

- demografische transitie: een afname van de relatieve sterfte en het relatieve aantal geboorten;

- epidemiologische transitie: een verschuiving van infectieziekten naar chronische ziekten;

- gezondheidszorgtransitie: verbeteringen in en aanpassingen van de gezondheidszorg (kennisontwikkeling, technologische innovaties, toenemende aandacht voor het verbeteren van de kwaliteit van leven).

De gezondheidstransitie - die de boven genoemde transities omvat kan grofweg aan de hand van de volgende fasen worden beschreven [6]: 


\section{1) Epidemieën, honger en oorlog}

Deze fase van de gezondheidstransitie wordt gekenmerkt door hoge sterftecijfers en hoge geboortecijfers. Het gebruik van natuurlijke hulpbronnen - bijvoorbeeld voedsel en water - is in deze fase gebrekkig. Er is onvoldoende sociaal kapitaal - denk aan kennis, sociale infrastructuur en onvoldoende economisch kapitaal. Daardoor hebben epidemieën, honger en oorlog een grote invloed op gezondheid en blijft de gemiddelde levensverwachting erg laag. Ziekten en aandoeningen worden voornamelijk bestreden met kruiden, aderlatingen en hekserij. Deze fase beslaat het grootste deel van onze geschiedenis.

\section{2) Afnemende infectieziekten}

In het midden van de negentiende eeuw vinden er in de huidige ontwikkelde landen belangrijke veranderingen plaats. Een goed voorbeeld is de sanitaire revolutie, waardoor de hygiënische omstandigheden sterk verbeteren. Onze kennis over gezondheid, ziekten en medicijnen - bijvoorbeeld antibiotica - neemt toe. De gezondheid wordt ook positief beïnvloed door een beter gebruik van de natuurlijke hulpbronnen zoals voedsel en water en door verbeterde economische en sociale omstandigheden. Deze ontwikkelingen leidden tot een daling in de prevalentie van infectieziekten, verbeterde overlevingskansen voor kinderen, een daling van de sterfte en een aanzienlijke stijging van de levensverwachting. Omdat het aantal geboorten niet daalt, wordt deze tweede fase ook gekenmerkt door een sterke bevolkingstoename.

In de ontwikkelingslanden vindt de sterke daling van infectieziektes en sterfte en de stijging van de levensverwachting pas veel later plaats. Lieten sommige ontwikkelingslanden de eerste voorzichtige daling van sterfte aan het begin van de twintigste eeuw zien, de echte daling begon pas na het einde van de Tweede Wereldoorlog. Dat was vooral een gevolg van volksgezondheidsmaatregelen zoals immunisatieprogramma's.

\section{3) Veroudering en de opkomst van chronische ziekten}

Tijdens de overgang naar de derde fase in de gezondheidstransitie stabiliseert de sterfte. Door de afnemende infectieziekten, de dalende geboortecijfers en de stijgende levensverwachting vindt er een vergrijzing van de bevolking plaats en een toename van chronische ziekten zoals hart- en vaatziekten. De gezondheidszorg, medische kennis en medische technologie verbeteren sterk en moeten zich aanpassen aan 
de toename van chronische ziekten en de behoeften van een oudere bevolking. Ook vindt er een verschuiving plaats in de belangrijkste determinanten van gezondheid, vooral door veranderingen in onze levensstijl (tabak- en alcoholconsumptie, ongezonde voeding en weinig beweging) en leefomgeving (bijvoorbeeld milieuproblemen en arbeidsklimaat).

Er bestaan echter grote verschillen tussen de diverse landen. De meerderheid van de ontwikkelingslanden bevindt zich bijvoorbeeld nog steeds in de tweede fase. De gezondheidstransitie die deze landen doorlopen wordt ook wel het 'vertraagde model' genoemd. Door de combinatie van hoge geboortecijfers en forse dalingen in de sterfte kampen deze landen met een sterke bevolkingsgroei. Het is nog onduidelijk of de ontwikkelingslanden hetzelfde pad als de ontwikkelde landen blijven volgen en uiteindelijk de infectieziekten 'omruilen' voor chronische ziekten. Sommige trends wijzen er namelijk op dat de ontwikkelingslanden in de toekomst zowel chronische ziekten als infectieziekten het hoofd zullen moeten bieden ('double burden of disease'), terwijl het niveau van de gezondheidszorg veelal te wensen overlaat. Een situatie die alles behalve duurzaam te noemen is.

\section{Een gezonde toekomst?}

Met behulp van het gezondheidstransitie-concept zijn zojuist de gezondheidsontwikkelingen in het verleden beschreven en geanalyseerd. De logische volgende stap is de verkenning van toekomstige gezondheid in de context van een mondialiserende wereld. Hiertoe maak ik gebruik van drie mogelijke toekomstige gezondheidssituaties [7]:

1. duurzame gezondheid, waarin zowel economische factoren als verbeteringen in sociaal-culturele en ecologische condities een positief effect op de gezondheid hebben;

2. medische technologie, waarin gezondheidsrisico's toenemen, bijvoorbeeld veroorzaakt door veranderingen in levensstijl en milieuveranderingen. Deze zullen echter tenietgedaan worden door economische groei en technologische ontwikkelingen;

3. opkomende infectieziekten, waarin de opkomst van nieuwe en oude infectieziekten een significant negatief effect op de gezondheidstoestand heeft, mede onder invloed van reizen en handel, microbiologische resistentie, problemen in de gezondheidszorg en toenemende milieuproblemen. 


\section{Toekomst A: een mondialiserende en marktgeoriënteerde wereld}

- Bevolkingsgroei: hoog, vooral in ontwikkelingslanden

- Ongelijkheid: neemt toe

- Onderwijs: verbeteringen; ontwikkelingslanden blijven achter

- Conflicten: spanningen en conflicten door sociale en ecologische problemen, vooral in ontwikkelingslanden

- Sociale condities: geen verbeteringen in de sociale infrastructuur; geen reductie van sociale problemen; vooral problemen in ontwikkelingslanden

- Homogenisatie van culturen: ja, normen en waarden van huidige geïndustrialiseerde landen

- Voedseltekort: neemt toe in ontwikkelingslanden

- Waterschaarste: groot in ontwikkelingslanden; sommige ontwikkelde landen ervaren ook problemen

- Milieu: toenemende milieuproblemen in zowel ontwikkelingslanden als ontwikkelde landen; ecosysteemdegradatie, vervuiling, verlies aan biodiversiteit

- Klimaatverandering: uiteindelijk merkbaar

- Economie: hoogste prioriteit; groei is hoog, maar ongelijk

- Technologie: vooruitgang en diffusie, maar ontwikkelingslanden hebben onvoldoende middelen voor brede toepassing van nieuwe technologieën

- Beleid: lage actieve betrokkenheid; vertrouwen in competitieve marktwerking en marktgebaseerde oplossingen; variërende effectiviteit in ontwikkelde landen; lage effectiviteit in ontwikkelingslanden

\section{Toekomst B: een gefragmenteerde en marktgeoriënteerde wereld}

- Bevolkingsgroei: hoog, vooral in ontwikkelingslanden

- Ongelijkheid: neemt snel toe

- Onderwijs: afnemend onderwijsniveau, vooral in ontwikkelingslanden

- Conflicten: groeiende spanningen; regelmatig conflicten

- Sociale condities: lage prioriteit; ongewenste sociale veranderingen; toenemende sociale stress en een slechter wordende sociale infrastructuur

- Homogenisatie van culturen: nee

- Voedseltekort: voedseltekorten nemen significant toe in ontwikkelingslanden; sommige ontwikkelde landen ervaren ook problemen

- Waterschaarste: neemt wereldwijd toe; grote problemen in ontwikkelingslanden

- Milieu: toenemende ecologische stress; afnemende milieukwaliteit; wereldwijd

- Klimaatverandering: ja, met negatieve effecten

- Economie: instabiliteit en fragmentatie door sociale en ecologische problemen; langzame groei in de ontwikkelde landen; rest van de wereld blijft achter

- Technologie: vooruitgang is zeer langzaam in rijkere regio's; geen verspreiding van technologische innovaties

- Beleid: grotendeels ineffectief; geen internationale samenwerking; actieve betrokkenheid van overheden varieert 


\section{Toekomst C: een mondialiserende en duurzame wereld}

- Bevolkingsgroei: laag of zelfs negatief; mogelijke bevolkingsafname in ontwikkelde landen

- Ongelijkheid: neemt af

- Onderwijs: verbeteringen, vooral in de ontwikkelingslanden

- Conflicten: zeldzaam

- Sociale omstandigheden: transformatie naar duurzame samenleving; verbeterde sociale infrastructuur; reductie van sociale problemen

- Homogenisatie van culturen: ja, de mentaliteit van de huidige consumptiemaatschappij verandert en duurzame normen en waarden worden belangrijk

- Voedseltekort: neemt af

- Waterschaarste: neemt af

- Milieu: transformatie naar ecologische duurzaamheid; verbeterende ecologische condities en herstellende ecosystemen

- Klimaatverandering: ja, maar uiteindelijk stabilisatie door grote emissiereducties

- Economie: groei blijft binnen de grenzen van duurzame ontwikkeling; toename in nonmateriële economische activiteiten; economische 'catch-up' van minder ontwikkelde regio's

- Technologie: vooruitgang (groene technologie, informatietechnologie) en diffusie

- Beleid: effectief; internationale samenwerking en mondiaal beleid; bottom-up processen; geen vertrouwen in marktwerking; participatief

Hoewel deze toekomstige gezondheidssituaties uiteraard fictief zijn, zijn ze wel gebaseerd op bestaande literatuur en kunnen ze worden beschouwd als mogelijke toekomstige fasen in de gezondheidstransitie. 'Incidenten' zoals de uitbraak en verspreiding van de nieuwe infectieziekte SARS laten ons zien wat in de toekomst onder bepaalde omstandigheden met onze gezondheid zou kunnen gebeuren.

Als we deze 'gezondheidsbeelden' koppelen aan scenario's met betrekking tot een mondialiserende wereld (zie boven en vorige pagina), zien we het volgende [8]:

Gezondheid in een mondialiserende en marktgeoriënteerde wereld In deze toekomst spelen economische groei, technologische ontwikkelingen en mondialisering een centrale rol. Dit leidt tot voortzetting van de huidige trends inzake sociale en ecologische problemen. Bevolkingsgroei (vooral in ontwikkelingslanden), migratie, regionale conflicten (wederom: vooral in ontwikkelingslanden), toenemende druk op voedsel en water, verlies van biodiversiteit, vervuiling en klimaat- 
verandering zullen de gezondheid negatief beïnvloeden. Hoewel de Derde Wereld deelneemt in de mondiale markt, zal de economische ongelijkheid blijven bestaan en zelfs groter worden. Daardoor zullen de ontwikkelingslanden zeker negatieve gezondheidseffecten ervaren als gevolg van de genoemde problemen. Hoewel nieuwe technologieën beschikbaar komen, zullen de ontwikkelingslanden deze waarschijnlijk niet kunnen betalen. In deze toekomst zullen de ontwikkelingslanden niet de derde fase van de gezondheidstransitie (veroudering en chronische ziekten) bereiken. Door de toenemende economische, sociaal-culturele en ecologische problemen zullen in deze landen geleidelijk meer en meer nieuwe en oude infectieziekten de kop op steken. Dankzij hun economische groei en (medisch-) technologische innovaties zullen de geïndustrialiseerde landen de meeste gezondheidsproblemen het hoofd kunnen bieden. Maar door een snelle verspreiding van infectieziekten zal in deze toekomst de dreiging van uitbraken van nieuwe en oude ziekten niet genegeerd kunnen worden.

\section{Gezondheid in een gefragmenteerde wereld}

Deze toekomst wordt gekenmerkt door een stagnatie in het mondialiseringsproces en een toename van regionalisme, gecombineerd met een marktgeoriënteerde instelling van de maatschappij. Economische groei zal alleen in de reeds ontwikkelde regio's plaatsvinden. Ook zullen alleen de rijke landen kunnen profiteren van technologische innovaties: in deze gefragmenteerde wereld vindt weinig diffusie van kennis plaats. In deze 'toekomst van ongelijkheid' zullen de armere landen onafwendbaar de eerste slachtoffers zijn van de negatieve gezondheidseffecten van voedsel- en waterschaarste, milieuproblemen, haperende sociale infrastructuur, conflicten, migratie, bevolkingsgroei, onvoldoende onderwijsmogelijkheden, inadequate gezondheidszorg en ineffectief beleid. De economie stagneert en de maatschappij bevindt zich in een neerwaartse spiraal. De sociale, economische en ecologische problemen zullen de ontwikkelingslanden snel leiden naar een toekomst van opkomende infectieziekten. Op de kortere termijn zullen de rijkere landen in staat zijn om negatieve gezondheidseffecten grotendeels te voorkomen. In eerste instantie zullen de meer ontwikkelde regio's hun huidige levensverwachting dus kunnen handhaven of zelfs verbeteren dankzij (medisch-) technologische ontwikkelingen. Maar deze situatie is voor de rijkere landen verre van stabiel. 
Gezondheid in een mondialiserende en duurzame wereld

Deze toekomst wordt gekarakteriseerd door zowel economische groei en mondialisering als door toename van het sociale en ecologische bewustzijn. Duurzaamheid heeft een hoge prioriteit en de economische groei blijft binnen de grenzen van sociale en ecologische doelen - onder andere door een mentaliteitsverandering in de huidige consumptiemaatschappij en effectieve beleidsmaatregelen. Dit resulteert in een afname van de risico's voor de volksgezondheid door stabilisatie van de bevolkingsomvang, verbeteringen in onderwijs, afname van conflicten en spanningen, toegenomen milieukwaliteit, afname van voedsel- en waterproblemen en technologische innovaties en diffusie. Heel belangrijk is de reductie van het economische en sociale verschil tussen de huidige ontwikkelingslanden en de geïndustrialiseerde wereld. Deze toekomst beschrijft een transitie naar een duurzame samenleving, waardoor de gezondheidssituatie zich gunstig kan ontwikkelen. Zowel de ontwikkelde als de ontwikkelingslanden zullen duurzame gezondheid kunnen bereiken.

Onze gezondheid wordt dus in toenemende mate bepaald door factoren die de landsgrenzen overschrijden. Tegelijkertijd worden landelijke gezondheidszorgsystemen steeds vaker beïnvloed door gebeurtenissen op mondiale schaal. In een wereld waar landen en economieën steeds meer van elkaar afhankelijk zijn, is slechte gezondheid in welke bevolking dan ook van invloed op álle volkeren - arm of rijk.

Het sturen van de gezondheidstransitie naar een tijdperk van duurzame gezondheid vereist een beleid dat sociale, economische en milieusectoren omvat. Het besturen van deze transitie vereist ook een microbenadering die rekening houdt met de sociale-, culturele- en gedragsfactoren die gezondheid bepalen. Maar zo'n microbenadering zal alleen duurzaam zijn in combinatie met een macrobenadering.

Op macroniveau is er het sterke en groeiende bewijs van de relatie tussen armoedebestrijding, onderwijs, lagere geboortecijfers en betere gezondheid. Een verlaging van het sterftecijfer kan niet alleen worden bewerkstelligd door een snelle macro-economische ontwikkeling, maar ook door beleid dat ontworpen is om aan de fundamentele behoeftes van de meerderheid van de bevolking te voldoen. 
Een snelle vooruitgang in de gezondheidstransitie vereist dan ook dringende, grootschalige investeringen - in opleiding, maar ook in herstructurering van de gezondheidssystemen, zodat die ook voor minderbedeelden toegankelijk zijn. Tegelijkertijd moeten op internationaal niveau maatregelen worden getroffen om te waarborgen dat de gezondheidseffecten als gevolg van veranderingen in het mondiale milieu tot een minimum zullen worden beperkt. Een voorbeeld in dit verband is het terugdringen van broeikasgasemissies om de gezondheidseffecten van de in de komende decennia verwachte klimaatverandering te verminderen.

\section{Duurzaamheidswetenschap: een nieuw paradigma}

Het voorbeeld 'gezondheid' illustreert duidelijk de complexiteit van duurzame ontwikkeling. Het geeft ook een aantal praktische elementen en hindernissen weer, waar rekening mee gehouden moet worden. Zo bestaat er weinig twijfel over de notie dát geïntegreerde onderzoeksbenaderingen nodig zijn om een duurzame ontwikkeling te ondersteunen. Het hóe en de daadwerkelijke uitvoering van zo'n integratie - ondersteund door goed onderbouwd onderzoek - blijven vooralsnog voorbehouden aan een selecte groep.

Op mondiale schaal is in het kader van het internationale 'Global Change'-onderzoeksprogramma geweldige vooruitgang geboekt bij de integratie van voorheen gescheiden disciplines. Vijftien jaar geleden zouden atmosferische chemici en biologen bij de bestudering van atmosferische veranderingen hun kennis niet hebben gedeeld ondanks het feit dat biologische processen een belangrijke regulerende factor zijn in de samenstelling van de lucht. Ook waren beide disciplines niet goed geïntegreerd in de atmosferische fysica, de oceanografie of het klimaatonderzoek. Tegenwoordig zijn al deze disciplines veel nauwer met elkaar verbonden en vormen ze de kern van onze kennis over mondiale (klimaat)veranderingen, gebaseerd op geïntegreerd onderzoek en risicoanalyse.

De internationale onderzoeksgemeenschap op het gebied van mondiale verandering heeft dus al grote vooruitgang geboekt in het koppelen van de diverse natuurwetenschappen. Er is echter - ondanks grote nationale en internationale inspanning - veel minder voortgang geboekt waar het gaat om ons inzicht in de interacties tussen mens en milieu. 
Om de hooggespannen verwachtingen waar te kunnen maken, is een nieuw onderzoeksparadigma nodig dat een betere afspiegeling geeft van de complexiteit en het eerder genoemde multidimensionale karakter van duurzame ontwikkeling. Het nieuwe paradigma moet meervoudige schaalgroottes (tijd, ruimte en functie), meervoudig evenwicht (dynamiek), meerdere spelers (belanghebbenden) en meervoudig falen (systeemfouten) kunnen hanteren.

Dit nieuwe paradigma komt voort uit een wetenschappelijke onderstroom die de evolutie van de wetenschap in het algemeen kenmerkt een verschuiving van modus-1 naar modus-2 wetenschap (zie Tabel 1) [9]. Modus-1 wetenschap is volledig academisch van aard, monodisciplinair en wetenschappers zijn hoofdelijk verantwoordelijk voor hun eigen wetenschappelijke prestaties. In modus-2 wetenschap - die in de kern inter- en intradisciplinair is - maken de wetenschappers deel uit van heterogene netwerken. Hun wetenschappelijke taken zijn onderdeel van een uitgebreider proces van kennisproductie en zij zijn verantwoordelijk voor meer dan wetenschappelijke productiviteit alleen.

Een ander paradigma met toegenomen invloed is de notie van postnormale wetenschap. Het is onmogelijk onzekerheden in besluitvormingsprocessen uit te bannen. Daarom moeten ze adequaat beheerst worden door georganiseerde participatieve processen waarin verschillende soorten kennis - en niet alleen wetenschappelijke kennis - bij elkaar komen. Hierdoor wordt de beleidsvorming zo goed mogelijk ingelicht over complexe maatschappelijke problemen van groot belang.

Tabel 1: Enkele eigenschappen van modus-1 en modus-2 wetenschap

\section{Modus-1 wetenschap}

Academisch

Monodisciplinair

Technocratisch

Zekerheid

Voorspellend

\section{Modus-2 wetenschap}

Academisch en maatschappelijk

Trans- en interdisciplinair

Participatief

Onzekerheid

Verkennend

Het onderzoeksprogramma dat uit deze bewegingen begint voort te komen, heeft de naam Sustainability Science of duurzaamheidswetenschap gekregen [10]. Het virtuele Forum on Science and Technology for Sustainability is op dit moment een van de motoren achter dit program- 
ma [11]. Duurzaamheidswetenschap is echter nog geen zelfstandig vak, laat staan een discipline. Het is eerder een levendig gebied waarin wetenschap, praktijk en visies van Noord en Zuid elkaar ontmoeten, met bijdragen uit het hele spectrum van de natuur-, economische, en sociale wetenschappen. Duurzaamheidswetenschap wordt gekenmerkt door een aantal gedeelde onderzoeksprincipes. 'Gedeeld' impliceert hier een brede herkenning door een groeiende groep mensen die - in zich steeds verder uitbreidende netwerken - werkzaam is op het gebied van de duurzaamheidswetenschap. Centrale elementen hiervan zijn:

- inter- en intradisciplinair onderzoek

- co-productie van kennis

- co-evolutie van een complex systeem en zijn omgeving

- leren door te doen en doen door te leren

- systeeminnovatie in plaats van systeemoptimalisatie.

Eenvoudig gesteld kan dit nieuwe model worden gekenschetst als co-evolutie, co-productie en co-leren. De theorie van complexe systemen kan worden gebruikt als overkoepelend mechanisme om de verschillende delen van de duurzaamheidspuzzel samen te voegen.

\section{Geïntegreerde duurzaamheidsanalyse}

Dit nieuwe paradigma heeft vergaande gevolgen voor de methoden en technieken die ontwikkeld moeten worden voor de uitvoering van een geïntegreerde duurzaamheidsanalyse. Deze nieuwe methoden en technieken worden ook gekenmerkt door de volgende eigenschappen:

- van aanbod- tot vraaggestuurd

- van technocratisch tot deelnemend

- van objectief tot subjectief

- van voorspellend tot verkennend

- van zekerheid tot onzekerheid.

Kortom, het karakter van onze geïntegreerde analyse-instrumenten is aan het veranderen. Terwijl voorgaande generaties van die instrumenten als 'waarheidsmachines' werden beschouwd, worden de huidige en toekomstige generaties meer als heuristische instrumenten gezien, als hulpmiddelen bij het verkrijgen van beter inzicht in complexe duurzaamheidsproblemen. In elke onderzoeksfase van de duurzaamheids- 
wetenschap moeten dus nieuwe methoden en technieken gebruikt, uitgebreid of uitgevonden worden. De methodieken die binnen de integrated assessment-gemeenschap gebruikt en ontwikkeld worden, zijn hiervoor uitermate geschikt.

Grofweg is er een aantal soorten methoden voor het geïntegreerd beoordelen ('integrated assessment') van duurzaamheid: analytische methoden, participatieve methoden en meer bestuurlijke methoden. Analytische methoden kijken vooral naar de aard van duurzame ontwikkeling, daarbij onder andere gebruik makend van de complexiteitstheorie. In participatieve onderzoeksbenaderingen spelen ook niet-wetenschappers, zoals beleidsmakers, vertegenwoordigers uit het bedrijfsleven, maatschappelijke organisaties en burgers een actieve rol. De meer bestuurlijke methoden onderzoeken de beleidsmatige aspecten en de beheersbaarheid van duurzame transities.

Een voorbeeld van een analytisch instrument voor het beoordelen van duurzaamheid is het geïntegreerde model (integrated assessment model), waarmee veranderingen tussen perioden van dynamisch evenwicht kunnen worden beschreven en verklaard. Dit geïntegreerde model bevat een systeemdynamische weergave van de drijfveren, systeemveranderingen, gevolgen, terugkoppelingen, potentiële lock-ins en lockouts van een bepaalde ontwikkeling in een specifiek gebied. Een ander analytisch instrument is het scenario dat (on)duurzame ontwikkelingen beschrijft, inclusief onverwachte gebeurtenissen, verrassingen en breuklijnen.

Participatieve methoden verschillen naar gelang het doel van een studie en de deelnemers hieraan. Zo kunnen onderhandelingsprocessen worden nagebootst in zogenaamde beleidsoefeningen, al dan niet ondersteund door simulatiespelen. Bij de methode van wederzijds leren wordt de analyse verrijkt door het integreren van kennis van deelnemers met uiteenlopende expertise.

Een voorbeeld van een nieuwe soort beleidsinstrument is transitiemanagement [12]. Transitiemanagement is een visionair, evolutionair leerproces dat is opgebouwd uit opeenvolgende stappen:

(i) ontwikkeling van een langetermijnvisie op duurzame ontwikkeling en een gemeenschappelijke agenda (macroschaal);

(ii) formulering en uitvoering van plaatselijke, vernieuwende experi- 
menten die misschien kunnen bijdragen aan de overgang tot duurzaamheid (microschaal);

(iii) evaluatie en leren van deze micro-experimenten;

(iv) bijstelling van de duurzaamheidsvisie en -strategie, gebaseerd op wat men geleerd heeft.

Dit komt neer op een cyclisch zoek- en leerproces dat evolutionaire sturing wordt genoemd. Een nieuw soort planning met verstand, gebaseerd op leren door te doen en op doen door te leren.

Maar nu de eerste stappen naar een integrerende duurzaamheidswetenschap gezet zijn, liggen grote sprongen voorwaarts in het verschiet.

\section{Naar een strategie voor duurzame ontwikkeling}

Doorbreken van barrières

Een onderzoekskader voor duurzaamheidswetenschap zal op bestaande wetenschappen en wetenschappelijke programma's moeten voortbouwen. Ook heb ik laten zien dat de voornaamste kansen en bedreigingen voor de duurzaamheidstransitie meervoudig, cumulatief en interactief zijn. Echter, om de duurzaamheid van de interactie tussen de aarde, haar ecosystemen en volkeren te kunnen bestuderen, is meer nodig.

Het zal duidelijk zijn dat duurzaamheidswetenschap vooral een integrerende wetenschap zal moeten worden. Een wetenschap die zich inzet voor het doorbreken van de barrières die de traditionele wetenschappen scheiden. Zij moet de integratie bevorderen tussen verschillende wetenschappelijke disciplines zoals economie, aardwetenschappen, biologie, sociale wetenschappen en technologie.

Hetzelfde kan gezegd worden voor de sectorale benaderingen die nauw met elkaar verbonden menselijke aspecten als energie, landbouw, gezondheid, vervoer en verkeer als afzonderlijke onderwerpen blijven behandelen.

De belangrijkste bedreigingen voor duurzaamheid treden op in specifieke regio's, met specifieke sociale en ecologische kenmerken. Een duurzame transitie zal dan ook vaak moeten plaatsvinden binnen lokale omgevingen. Echter, de duurzaamheidswetenschap moet ook op geografische schaal integratie bevorderen - om zo de soms gemakkelijke 
maar uiteindelijk kunstmatige scheiding tussen mondiale en plaatselijke perspectieven teniet te doen. Ongeacht welke ruimtelijke schalen het meest geschikt worden bevonden om bepaalde kwesties van duurzaamheid te onderzoeken, het krijgen van inzicht in de verbanden tussen gebeurtenissen op macro- en microschaal is één van de grootste uitdagingen van de duurzaamheidswetenschap $[1,13]$.

De duurzaamheidswetenschap moet, ten slotte, verschillende stijlen van kenniscreatie zien te integreren om zo de kloof te overbruggen tussen wetenschap, praktijk en politiek.

\section{Duurzaam beleid}

Als we kijken naar de consequenties van deze nieuwe 'duurzaamheidsvisie' voor het beleid, kunnen we het volgende constateren. Voor beleidsmakers, zowel in de politiek als in het bedrijfsleven, is het van belang dat er bepaalde beleidsdoelen en het daarmee gemoeide tijdsbestek worden bepaald. In het schema (Figuur 2) is een aantal mogelijkheden te zien. Een van de opties die een beleidsmaker heeft - en dat staat niet ver van de huidige situatie - is kiezen voor kortetermijndoelen en eenvoudige of goedkope maatregelen om deze doelen te bereiken. In contrast daarmee staat een meer pro-actief, innovatief standpunt dat naar langetermijndoelen streeft en rekening houdt met ontwikkelingen op verschillende schaalniveaus en in verschillende sectoren. Duurzame ontwikkeling vereist zonder meer het laatste standpunt.

Om besluitvorming te vergemakkelijken moet de duurzaamheidswetenschap hulp bieden bij het concretiseren van zowel de problemen als de oplossingen - op alle relevante schalen van ruimte en tijd. Dit betekent dat duurzaamheid op systeemniveau moet worden beoordeeld, met als elementen: analyse van de dieperliggende structuren van het systeem en projectie in de toekomst en beoordeling van (niet-)duurzame trends. Hierbij hoort ook de evaluatie van het effect van duurzaam beleid en het ontwerp van mogelijke oplossingen door duurzame strategieën.

Gelukkig zijn geïntegreerde benaderingen van duurzaamheidsvraagstukken op onder andere milieu- en ontwikkelingsvlak niet geheel nieuw. Zo wordt er bijvoorbeeld al onderzoek gedaan naar de interacties tussen stedelijke, agrarische, industriële en natuurlijke ecosystemen, om meer inzicht te krijgen in de beleidsimplicaties voor het waterbeheer. 
Het zoeken naar geïntegreerde theorieën die disciplinaire sterktes combineren is bij uitstek een manier om een betere basis voor besluitvorming over duurzaamheid te creëren

\section{Integratieniveau}

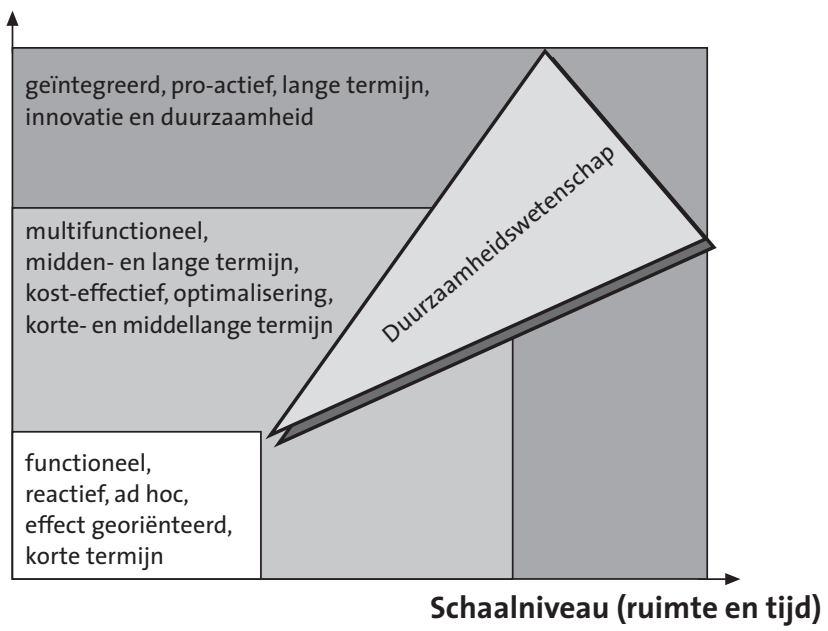

Figuur 2: Duurzaamheidswetenschap in het beleidsproces

\section{Duurzaam onderwijs}

Het zal u niet verbazen dat de ontwikkeling van een gezonde, rechtvaardige en duurzame samenleving vraagt om een grote verschuiving in ons denken, in onze waarden en onze acties.

Onze huidige studenten zullen de zakelijk leiders, de wetenschappelijke onderzoekers, de politici, kunstenaars en burgers van morgen worden De mate waarin zij bereid zullen zijn om beslissingen te nemen ten gunste van een duurzame toekomst hangt af van het besef, de kennis, vakkundigheid en waarden die zij tijdens hun studie en de jaren erna opdoen. Daarom moeten duurzaamheidsconcepten en -thema's op alle niveaus in onderwijsprogramma's ingebouwd worden. Curricula moeten herzien worden zodat duurzame ontwikkeling een leidraad vormt tijdens de gehele studie - en ook nog daarna. Dit besef wordt gelukkig door een steeds grotere groep mensen gedeeld. Zo heeft de Verenigde Naties de komende 10 jaar (2005-2014) uitgeroepen tot de 'Decade of 
Education for Sustainable Development'.

De basiskwaliteiten die toekomstige duurzaamheidswetenschappers moeten hebben zijn: analytisch inzicht, probleemoplossende kwaliteiten en goede vaardigheden in verbale en schriftelijke presentatie. Niet minder belangrijk is kennis van de instrumentaria die door de diverse betrokken disciplines worden aangeleverd. Die disciplines variëren van wiskunde tot geschiedenis, van gezondheidswetenschappen tot economie. Het scala aan vaardigheden dat nodig is, is zo breed dat het eigenlijk alleen door een interdisciplinaire studie verkregen kan worden.

Een andere noodzakelijke kwaliteit is het vermogen de eerder genoemde barrières te slechten tussen de betrokken wetenschappelijke disciplines, de beleidsmakers en de burgers. Minstens zo belangrijk ten slotte is grote toewijding, ook aan de filosofie en de ethiek die de basis vormen van duurzaamheidswetenschap. Op dit moment echter is er in de duurzaamheidswetenschap een gebrek aan fundamenteel en toegepast 'onderzoeksvermogen'. Daarnaast is er behoefte aan een grotere verscheidenheid aan benaderingen. Dit maakt het noodzakelijk dat we al het mogelijke in het werk moeten stellen om die extra capaciteit in de komende decennia op het noordelijk én zuidelijk halfrond op te bouwen.

Gelukkig zijn er wereldwijd verschillende initiatieven om het begrip duurzame ontwikkeling in onderwijsprogramma's te integreren. Ook de kennisinstellingen in deze regio zijn hierin actief. Zo speelt 'duurzame ontwikkeling' een belangrijke rol binnen de Faculteit der Natuurwetenschappen van de Open Universiteit Nederland en de Hogeschool Zuyd, onder andere via de bijdragen aan het Regionale Expertise Centrum 'Leren voor Duurzame Ontwikkeling' en de integratie van 'duurzame ontwikkeling' in de verschillende onderwijsprogramma's binnen deze kennisinstellingen. Aan de Universiteit Maastricht kunnen verschillende vakken betreffende duurzame ontwikkeling gevolgd worden bij het University College Maastricht. Ook is mogelijk 'Duurzame Ontwikkeling' als afstudeervariant te kiezen binnen het nieuwe masterprogramma 'Public Policy and Human Development', dat onder de vlag van de Maastricht Graduate School of Governance ontwikkeld wordt.

Een bescheiden maar volgende stap naar duurzame ontwikkeling in een van de regio's waar nog veel duurzaamheidswinst te halen valt - 
het Afrikaanse continent - is de ontwikkeling van het masterprogramma 'Governance for Sustainability' aan de Universiteit van Cape Coast in Ghana. Hierbij zijn de Universiteit van Amsterdam, de Maastricht School of Management en de Universiteit Maastricht betrokken.

\section{Tot slot}

Richard Feynman, een van de grootste natuurkundigen van de vorige eeuw, merkte ooit het volgende op over zijn vakgebied: "Wie zegt dat hij de kwantumtheorie begrijpt, doet dat waarschijnlijk niet." Dit geldt ook voor duurzame ontwikkeling. Wie zegt dat hij weet wat 'duurzaamheid' is, weet dat waarschijnlijk niet. In zekere zin is een duurzame wereld dan ook een fictie.

Zo beschouwt het concept duurzame ontwikkeling geen statische toestanden of eindige voorraden, maar benadrukt het een positieve evolutie en positieve ontwikkelingsrichtingen. Duurzame ontwikkeling kan dan ook worden omschreven als 'het vermogen van een maatschappij om zich binnen een bepaald tijdsbestek te kunnen bewegen tussen bevredigende, aan te passen en levensvatbare omstandigheden' [14].

Zoals ik heb proberen uit te leggen is het echter wél mogelijk een wetenschappelijke fundering onder het begrip duurzame ontwikkeling te leggen. Daar kan ook een praktische invulling aan gegeven worden. Dat kan variëren van duurzame gezondheid tot duurzaam gebruik van onze oceanen en rivieren, van duurzaam toerisme tot duurzaam ondernemen en duurzame regionale ontwikkeling. De unieke samenwerking tussen de Universiteit Maastricht, de Open Universiteit Nederland en de Hogeschool Zuyd, gebundeld in de leerstoel 'Duurzame Ontwikkeling', vormt hiervoor een goede basis.

De provincie heeft zich met het programma Naar een Duurzaam Limburg uitgesproken voor het maken van duurzame keuzes. Naast het vormgeven van een onafhankelijke visie op duurzame ontwikkeling in de regio, kan de leerstoel een ondersteunde rol vervullen bij het ontwikkelen van inzichten en vaardigheden om meer duurzame afwegingen in Limburg te kunnen maken. 
Andere maatschappelijke partijen zoals het bedrijfsleven moeten ook aangemoedigd worden om hun verantwoordelijkheid te nemen voor een duurzame toekomst. Zij moeten zodanig gemobiliseerd worden dat zij actief gaan meedoen aan het vormgeven van duurzame ontwikkeling, onder meer in Limburg en de Euregio. Het verheugt me dat dit al gestalte krijgt in de vorm van het eerder genoemde expertisecentrum 'Leren voor duurzame ontwikkeling'. Het brede maatschappelijke draagvlak dat hierdoor wordt verkregen, zal een voorwaarde zijn om het abstracte begrip 'duurzame ontwikkeling' concreet en tastbaar te maken. 


\section{Dankwoord}

Ik kom aan het einde van mijn rede en wil haar besluiten met een dankwoord. Allereerst dank ik de colleges van bestuur van de Universiteit Maastricht, de Open Universiteit Nederland en de Hogeschool Zuyd voor het gezamenlijk instellen van de bijzondere leerstoel Duurzame Ontwikkeling en voor het in mij gestelde vertrouwen. Ook wil ik de Provincie Limburg bedanken voor haar rol in het tot stand komen van deze leerstoel.

Veel dank ben ik verschuldigd aan degenen die mij in mijn wetenschappelijke ontwikkeling hebben geïnspireerd, gesteund en waar nodig gecorrigeerd - en dit nog altijd doen.

Hooggeleerde Rotmans, beste Jan. Zonder jou had ik hier niet gestaan. Zo'n twaalf jaar geleden leerde ik je kennen en sindsdien ben jij mijn mentor geweest: als stagebegeleider, als promotor op het RIVM en later als collega bij het ICIS in Maastricht. Ik dank je voor je aanstekelijk enthousiasme voor innovatief en integrerend onderzoek, en ik verheug me op de voorzetting van onze samenwerking.

Hooggeleerde Vrieze, beste Koos. Jij was degene die me al tijdens mijn studie de kans gaf om in de inspirerende omgeving van de vakgroep wiskunde de eerste wetenschappelijke stappen te zetten. Een betere start had ik me niet kunnen wensen.

Mijn dank gaat ook uit naar alle collega's van het ICIS aan de Universiteit Maastricht, waarmee ik niet alleen de afgelopen jaren met plezier heb samengewerkt, maar die ook nu zorgen voor een fijne en inspirerende werkomgeving.

Mijn collega's van de Faculteit der Natuurwetenschappen aan de Open Universiteit Nederland dank ik voor hun enthousiasme, deskundigheid en hulp bij het koppelen van innovatieve vormen van kennisoverdracht aan het concept 'duurzame ontwikkeling'.

De leden van de kenniskring Duurzame Ontwikkeling aan de Hogeschool Zuyd wil ik bedanken voor de plezierige discussies over de vertaling van het begrip duurzame ontwikkeling naar de praktijk en het hoger onderwijs. 
Pap en mam. Bedankt voor alle steun door de jaren heen. Jammer dat pap er niet bij kan zijn - ik weet zeker dat hij erg trots zou zijn geweest.

Lieve Petra, Robin en Timo. Jullie geven mij de liefde, inspiratie en de fijne thuishaven die het mij mogelijk maken om te doen wat ik doe.

Ik heb gezegd. 


\section{Referenties}

1. National Research Council, Our common journey: a transition toward sustainability. 1999, Washington, D.C.: National Academy Press.

2. WCED, Our common future. 1987, Oxford,UK: Oxford University Press.

3. Rotmans, J., et al., Duurzame ontwikkeling; van concept naar uitvoering. 2001, International Centre for Integrative Studies: Maastricht.

4. Martens, P., A.J. McMichael, and J. Patz, Globalisation, environmental change and health. Global Change and Human Health, 2000. 1(1): p. 4-8.

5. Bradley, D.J., et al., Health and sustainable development, in WSSD briefing paper. 2001.

6. Omran, A.R., The epidemiological transition theory revisited thirty years later. World Health Statistics Quarterly, 1998. 51: p. 99-199.

7. Martens, P., Health transitions in a globalising world: towards more disease or sustained health? Futures, 2002. 37(7): p. 635-648.

8. Martens, P. and M.M.T.E. Huynen, A future without health? The health dimension in global scenario studies. Bulletin of the World Health Organisation, 2003. 81(12): p. 896-901.

9. Gibbons, M., The new production of knowledge: the dynamics of science and research in comtemporary science. 1994, London: Sage.

10. Kates, R.W., et al., Sustainability science. Science, 2001. 292: p. 641-642.

11. Forum on Science and Technology for Sustainability: http://sust.harvard.edu.

12. Rotmans, J., Transitiemanagement: sleutel voor een duurzame samenleving. 2003, Assen: Koninlijke Van Gorcum.

13. Rotmans, J. and D. Rothman, eds. Scaling in integrated assessment. 2003, Swets \& Zeitlinger: Linne.

14. Giampietro, M., Complexity and scales: the challenge for integrated assessment, in Scaling in integrated assessment, J. Rotmans and D.S. Rothman, Editors. 2003, Swets \& Zeitlinger: Linne. p. 293-327. 
